\title{
Passwords
}

Volume 12 | Issue 2

Article 18

6-4-2012

\section{Camel Girl}

Robin Xu

rx002011@mymail.pomona.edu

Follow this and additional works at: http://scholarship.claremont.edu/passwords

Part of the Art and Design Commons, Creative Writing Commons, and the Photography Commons

\section{Recommended Citation}

Xu, Robin (2012) "Camel Girl," Passwords: Vol. 12: Iss. 2, Article 18. DOI: 10.5642/passwrd.20121202.18

Available at: http://scholarship.claremont.edu/passwords/vol12/iss2/18

This Poetry is brought to you for free and open access by the Journals at Claremont at Scholarship @ Claremont. It has been accepted for inclusion in

Passwords by an authorized administrator of Scholarship @ Claremont. For more information, please contact scholarship@cuc.claremont.edu. 


\section{Camel Girl}

Robin $\mathrm{Xu}$

They all say she must be crazy.

With that wild hair and those hazy eyes

She sits on the grass, rain or shine, and taps

The nonsense from her mind into words on paper

\section{Camel Girl.}

She's been an insomniac since she was four.

Worse, she's felt somewhat like a Beast of burden

And cursed at least since seventeen

When she and Daddy-o first met.

(Whenever she gets upset

She wishes she were less transparent

Or maybe just that he were a little more so.)

Camel Girl loves her Daddy-o.

She knows he's a genius, though she's not sure why.

Sweet like a gentleman, he opens her door

But he is impossible to please.

Sometimes she pokes her tongue out to tease him

But the closest she gets to a smile is a sigh.

Camel Girl is tired of all the lies.

Daddy-o is kind of like a Father but not quite.

She cries when he leaves her easily

Like please, you love me, please, please

(Camel Girl has had four humps

Three of which she enjoyed

But only one of which she is still in Love with.)

They all say he drove her crazy.

With his dark stare and his hazy lies

She wants him only day and night and

There is no relief in her mind but putting words on paper 
Camel Girl hides her camels in the closet.

There they lie, nearly too close to handle.

Their noses poking out and teasing

Like please, you need me, please, please

She only gives in on late night walks

When his lights are near

And the tears begin to fall

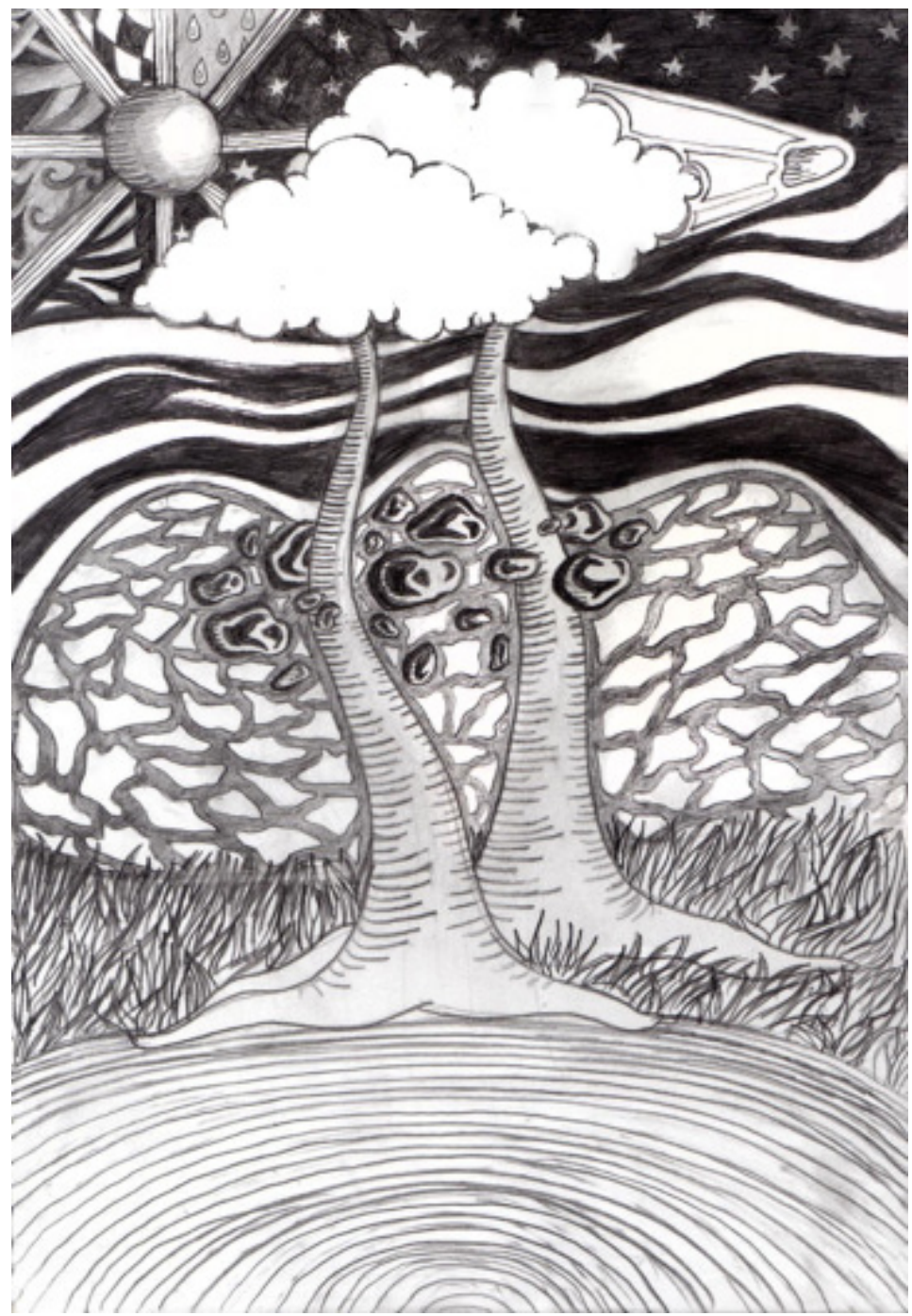

Olivia Weissblum 